\title{
Social mobility and the demand for income redistribution in Latin America
}

\author{
Cleiton Roberto da Fonseca Silva and Erik Alencar de Figueiredo
}

ABSTRACT

\begin{abstract}
Alesina and Angeletos (2005) and Alesina and Glaeser (2004) argue that income redistribution preferences vary systematically between the different regions and influence the size of government and the composition of public spending. This article analyses the demand for redistribution in Latin America, paying particular attention to the effects of mobility expectations on this demand. The findings suggest that demand for redistribution is driven primarily by self-interest and by considerations of fairness based on the inequality of opportunities. They also reveal the importance of past mobility, while the prospect of upward mobility (POUM) hypothesis advanced by Benabou and Ok (2001) is rejected in the case of the Latin America region.
\end{abstract} in Economics of the Federal University of Paraíba, Brazil. cleiton.roberto@yahoo.com.br

Erik Alencar de Figueiredo is a professor at the Department of Economics of the Postgraduate Programme in Economics of the Federal University of Paraíba and a researcher with the National Council for Scientific and Technological Development (cNPq), Brazil. eafigueiredo@gmail.com 


\section{I}

\section{Introduction}

What are the factors determining the demand for income redistribution in different societies? The question is particularly important because the answer can help to explain the size of government (why it is so large in some countries and so small in others) and because it provides a basis for establishing mechanisms to promote efficiency in resource allocation in cases where taxation distorts incentives.

Alesina and Angeletos (2005) and Alesina and Glaeser (2004) concentrate on the first point, arguing that different beliefs about the determinants of social competition can explain the differences in countries' redistribution policies. In this context, two basic types of equilibrium are distinguished. In places where effort is thought to be the main source of income differentials, there is less demand for redistribution. Because limited redistribution means low taxes, this creates a virtuous equilibrium encompassing limited taxation, high investment and incentives to effort. This is what happens in the United States. In Europe, conversely, income is thought to be determined largely by luck or by factors beyond agents' control. In this case, the equilibrium is one of high taxes, low investment and disincentives to effort, so that redistribution is desirable. In other words, different historical experiences lead societies to different stationary states in which the various social beliefs and political situations are self-perpetuating (Alesina and La Ferrara, 2005).

Consistently with these results, Corneo and Gruner (2002) show that the preferences of agents in the former socialist countries differ from those of Western citizens. Individuals' attitudes to redistribution are taken to be a reflection of their value systems. Alesina and Fuchs (2007) use the "experiment" of German separation to test whether the economic situation affects individual preferences. The findings indicate that agents' preferences are modelled more profoundly by the political regime of the societies they live in.

The basic model used as the starting point for these studies was established by Meltzer and Richard (1981), who took a parsimonious context in which the only activities of government were redistribution and taxation in an environment with fully informed voters. In this case, the size of government is determined by the maximization of each agent's individual welfare. The general idea is that agents with incomes lower than the average voter's are more likely to support redistribution mechanisms.

Even from the "micro" standpoint, the results differ irrespective of whether current income, individual characteristics, self-interest variables or different conceptions of the mechanisms of fairness are considered. Gaviria (2007) and Ravallion and Lokshin (2000), for example, find significant differences between the redistribution preferences of men and women and between agents with different levels of education. Neustadt and Zweifel (2009) identify a positive relationship between income and the demand for redistribution in Switzerland, which contradicts the standard model put forward by Meltzer and Richard (1981).

As figure 1 shows, data from the Economic Commission for Latin America and the Caribbean (ECLAC) reveal that public-sector social spending as a proportion of gross domestic product (GDP) has grown consistently in the region. ${ }^{1}$ It is possible that this trend has been influenced by social demands, since (according to Latinobarómetro 2007 data) an average of $78 \%$ of the population of Latin America consider income distribution in their respective countries unfair.

The size of government in some countries that have experienced left-wing revolutionary upheavals suggests an equilibrium similar to that observed in the European countries. Countries like Brazil and Mexico began to open up macroeconomically in the 1980 s, and it is natural to expect a shift of this kind to be accompanied by greater income variability and demands for social protection in the face of competition. Ultimately, the expectation for most agents is that redistribution should operate as a form of real "insurance" against the uncertainty of future income.

While it is important to establish the factors determining the demand for redistribution, this is not straightforward. Initially, it could be argued, following the logic of Meltzer and Richard (1981), that the agents who support redistribution measures are those who

\footnotetext{
1 In the early $1990 \mathrm{~s}, 11.3 \%$ of GDP was allocated to social spending, which represented $44.9 \%$ of total public spending. The amount increased until by 2008-2009 the figures were $17.9 \%$ of GDP and $62.2 \%$ of total spending. Specifically, spending on social security and welfare rose from $4.4 \%$ to $7.9 \%$ of GDP in the period.
} 

and the demand for income redistribution (I), 2007

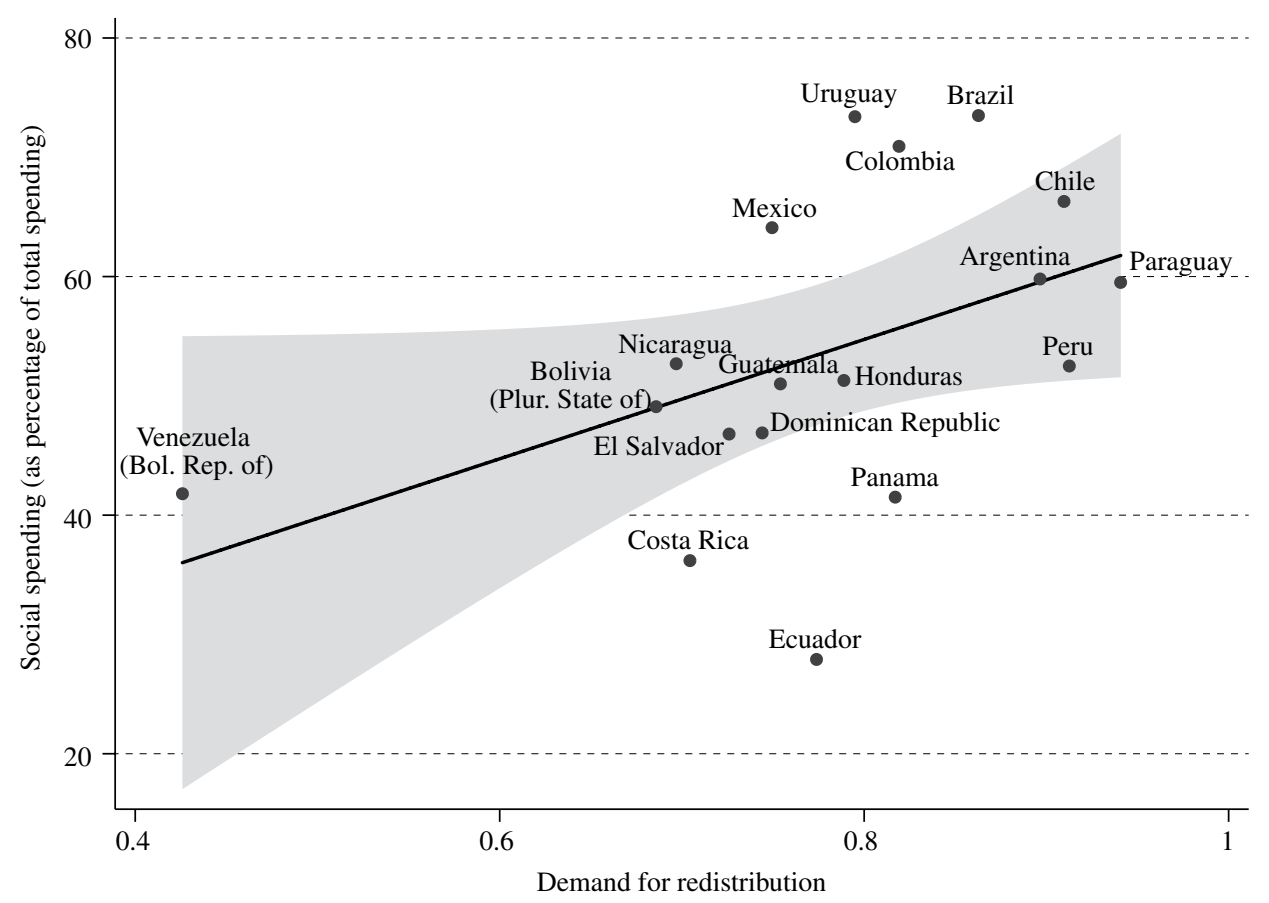

Source: prepared by the authors on the basis of data from the Economic Commission for Latin America and the Caribbean (ECLAC) and Latinobarómetro.

immediately benefit from the redistribution mechanisms. Some studies, such as that of Fong (2001), have shown that the matter is not so simple. Redistribution policies usually remain stable over time. Thus, even if some demand is allowed to be driven by pure self-interest, the uncertainty associated with factors such as mobility makes it hard to capture the effects of current income.

Someone who is poor today may be rich tomorrow, and vice versa. People's expectations about the future are crucial (Alesina and La Ferrara, 2005). Particularly important is the prospect of upward mobility (POUM), a phenomenon formalized by Benabou and Ok (2001) and tested in various empirical studies. The argument, in brief, is that the mass of agents with incomes just below the average may be against redistribution because they expect, quite rationally, to move above the average in future. Corneo (2001), Corneo and Gruner (2002) and Alesina and La Ferrara (2005) conclude that POUM influences the demand for income distribution in the different regions analysed. Will this finding hold good for Latin America too? According to Ravallion and Lokshin (2000), this hypothesis helps to explain tolerance for inequality in developing countries and accordingly merits a more thorough analysis.

The objective of this article is to study the demand for income redistribution in Latin America and, in particular, to analyse the role played by expectations of mobility, extending existing studies in the literature to a region of great interest. To this end, the article is divided into three sections in addition to this Introduction. Section II presents a theoretical discussion tied to the earlier studies as a starting point, after which section III details the empirical results and section IV sets forth the conclusions. 


\section{II}

\section{The demand for redistribution}

Studies analysing the demand for redistribution are usually based on the utility derived from agents' decisions. According to Ravallion and Lokshin (2000), expected utility is assumed to be the sum of current utility, known with certainty, and expected future utility. $f$ is defined as a "felicity" function that is twice-differentiable, strictly increasing and concave in $y$, while $H$ is the distribution of future income and $x$ is a vector of individual characteristics affecting expected income relative to current income. Utility without redistribution is expressed as follows:

$$
u(x, y)=f(y, x)+\int f(\tilde{y}, x) d H(\tilde{y}, x)
$$

The analysis with redistribution includes uncertainty about what tax will be imposed and about future income. It is assumed that the tax is given by $\tau(y, x)+\mu$, where $\mu$ is a random variable. Utility after redistribution, $v[y-\tau(y, x), x]$, takes the form

$$
\begin{gathered}
\int f[y-\tau(y, x)-\mu, x] d G(\mu, x)+ \\
\iint f[\tilde{y}-\tau(\tilde{y}, x)-\mu, x] d G(\mu, x) d H^{*}(\tilde{y}, x)
\end{gathered}
$$

where $H^{*}$ is the cumulative distribution function of future income when redistribution takes place. If redistribution is not expected to alter the distribution, $H=H^{*}$ and $u\left(y^{*}, x\right)=v\left(y^{*}, x\right)$. In this case, the agent is indifferent to the proposed redistribution. If the distribution of future income (after redistribution) is preferred, then $u\left(y^{*}, x\right)<v\left(y^{*}, x\right)$. Thus, those preferring the redistribution will have a utility gain given by

$$
g(y, x)=v[y-\tau(y, x), x]-u(y, x)
$$

The aim of this empirical study is to ascertain why some individuals support redistribution and others do not. The equation $R=1$ [ $g(y, x)>0$ ], where $R$ is a dummy variable that captures the preference for redistribution and 1[.] is an indicator function, can be constructed for this. Assuming that $g(y, x)$ is linear in the parameters and has a normally distributed error term, it is possible to estimate it using an approach with a dichotomous dependent variable. In this case, the multivariate model for agent $j(=1, \ldots, n)$ is

$$
g\left(y_{j}, x_{j}\right)=\alpha+\beta y_{j}+\pi x_{j}+\varepsilon_{j}
$$

The vector of characteristics $x$ is constructed on the basis of the theoretical discussion. Basic individual characteristics are generally included. The demand for redistribution can be theoretically related to different variables. Alesina and La Ferrara (2005) present a nonexhaustive list that includes present income, expectation of future income, personal history of mobility, risk aversion, altruism and belief in equality of opportunities.

Current and future incomes test demand motivated by self-interest. Risk aversion is included because for some agents redistribution is an "insurance policy" against uncertainty. Belief in equality of opportunities can be used to infer whether the demand for redistribution is connected with a sense of fairness. People who do not believe there is full equality of opportunities probably regard redistribution as a form of social justice.

Mobility, in particular, is a factor of great interest that ties in with the work of Tocqueville (2003). In recent decades, the first seminal article relating the redistributive behaviour of agents to the perception of mobility was that by Hirschman and Rothschild (1973). To summarize, these authors argue that agents who have high incomes but expect to be disadvantaged by the mobility process will be favourable to redistribution. ${ }^{2}$ Although Benabou and Ok (2001) were the first to formalize a model in these terms, they constructed their hypothesis the other way around: agents in the lower income strata are against redistribution when they expect upward mobility to place them in a stratum above the average. It is even argued that the possibility of upward social mobility makes people with below-average incomes unwilling to support higher taxes, as they believe that they or their children might move up in the income distribution and therefore be hurt by such policies (Benabou and Ok, 2001, p. 447).

\footnotetext{
2 Hirschman and Rothschild (1973) dubbed this behaviour the "tunnel effect" because of an analogy used as an example.
} 
The prospect of upward mobility (POUM) hypothesis, as it is known, is based on three fundamental assumptions: (i) future income is a concave function of current income; (ii) agents are not excessively risk-averse; and (iii) redistribution policies are stable and are maintained over time. According to Neustadt and Zweifel (2009), a simplified formulation of the position put forward by Benabou and Ok (2001) can be discussed using a two-period example. If point (i) is allowed, $y_{\text {future }}=f\left(y_{\text {current }}\right)$, when $f^{\mathrm{n}}(y)=0 \forall$ and $\in\left[0, y^{\text {max }}\right]$. Without loss of generality, individuals with average incomes today, $\mu_{0}$, will obtain the same income tomorrow, $f\left(\mu_{0}\right)$. The concavity of the function implies that, with redistribution, the total gain to the poor is less than the total loss to the rich, so that $\mu_{1}<\mu_{0}$. In this context, agents with a current position between $\mu_{1}$ and $\mu_{0}$ who hope to receive a future income greater than the average income, $\mu_{i}>\mu_{1}$, will be against redistribution.

For greater clarity, the simple formalization proposed by Alesina and La Ferrara (2005) should be considered: the income before and after tax of a risk-neutral individual $i$ is determined respectively by $y_{i t}$ and $y_{i t}^{d}$. A two-period model with lump-sum linear taxation of $\tau$ is assumed. When $\bar{y}$ is established as the average income of the community (assumed to be constant in both periods), ignoring the deduction and assuming $E($.) as the expected value, the total income available to individual $i$ in the two periods is

$$
y_{i 1}^{d}+E\left(y_{i 1}^{d}\right)=(1-\tau)\left(y_{i 1}+E\left(y_{i 2}\right)\right)+2 \tau \bar{y}-\tau^{2} \bar{y}
$$

Maximizing this expression gives the preferred tax rate:

$$
\tau_{i}^{*}=1-\frac{1}{2 \bar{y}}\left(y_{i 1}+E\left(y_{i 2}\right)\right)
$$

In other words, the higher current and expected future income is, the lower the optimum level of redistribution. When a variable capturing expectations of future mobility is included in the empirical test, POUM means that the expectation of moving to a higher income stratum is associated with a lesser demand for redistribution.

\section{III}

\section{Empirical analysis}

\section{Data}

The data used in the study are based on the 2007 Latinobarómetro study, covering 18 countries of Latin America: Argentina, the Bolivarian Republic of Venezuela, Brazil, Chile, Colombia, Costa Rica, the Dominican Republic, Ecuador, El Salvador, Guatemala, Honduras, Mexico, Nicaragua, Panama, Paraguay, Peru, the Plurinational State of Bolivia and Uruguay. The questions used are detailed in annex A.

Some studies, like Alesina and Angeletos (2005), consider the following question in order to take respondents' position on the political spectrum as a proxy for the demand for redistribution: "In politics, people normally speak of 'left' and 'right'. On a scale where 0 is left and 10 is right, where would you place yourself?" The demand for redistribution is greater among respondents who place themselves on the left.

This was one of the variables employed by Gaviria (2007), who also used questions dealing with support for privatization and the market economy as dependent variables in a model for Latin America itself (1996-2000). However, the same author draws attention to the difference in the findings when position on the political spectrum is taken as a dependent variable.

To analyse the soundness of this question, the spontaneous answers were crossed with the answers delimiting the actual political stance of respondents, giving the same weight to individuals' opinions about: (i) the role of the market economy in development; (ii) the role of private enterprise in development; (iii) the effect of private-sector investment on employment opportunities; (iv) the effect of free competition on employment opportunities; (v) the effect of international free trade on employment opportunities, and (vi) the role of the State in solving society's problems.

The variable was formulated so that a higher value for the parameter indicates a more left-wing position. Thus, the equivalence between respondents' spontaneously declared position and their actual one should be manifested in a negative relationship that is fully established in figure 2 . Yet it can be seen that 


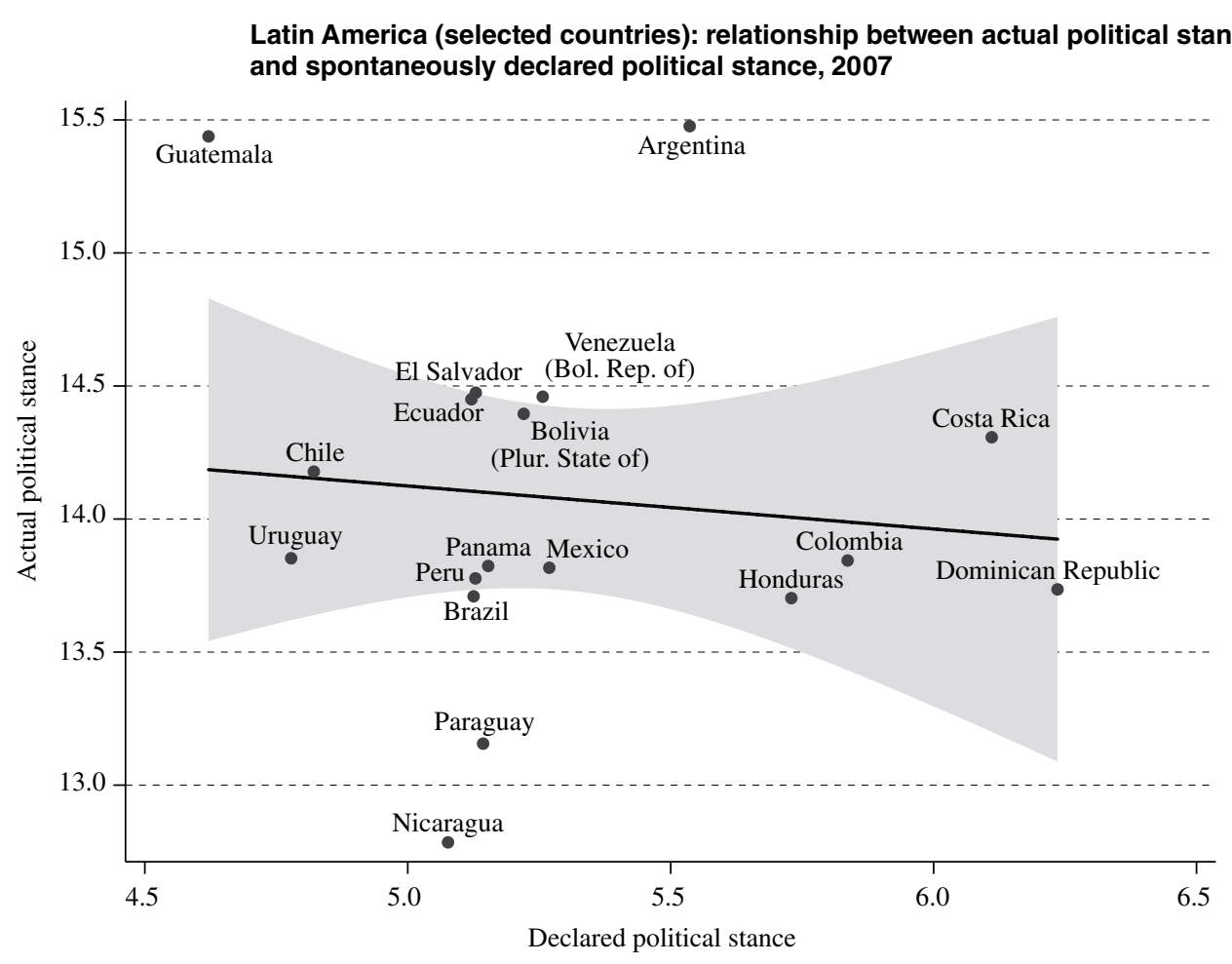

Source: prepared by the authors on the basis of Latinobarómetro data.

people's responses do not correspond to their actual political positions. Accordingly, use of respondents' spontaneously declared political stance as a proxy for the demand for redistribution is not advised, as this variable does not even capture their real political positions. ${ }^{3}$

While other studies such as Fong (2001) have used questions about the need for government to restrict the incomes of the rich, no questionnaire of this type is available in the database used. In any event, these questions assume a specific redistribution mechanism, and the answers will partly depend on people's belief in the ability of government to implement a transfer mechanism of this type.

In these circumstances, the decision was taken to use two questions that capture the perception of fairness in income distribution as proxies for the demand for redistribution. Questions of this type are more suitable than those that merely ask whether distribution is unequal,

3 It is not part of this article's purpose to investigate the issue. Ames and Smith (2010) have carried out a tightly focused but helpful discussion of the difficulty of establishing ideological identification in Brazil. as respondents who acknowledge the existence of inequality might consider it fair and thus not be calling for redistribution.

Nonetheless, the limitations of the questions need to be stressed, as they do not directly measure demand for redistribution. Even if respondents do consider the distribution of income to be unfair, they might be against a likely increase in taxes and thus against redistribution too. They might also have the fatalistic belief that "that's just the way it is" and come out against redistribution mechanisms. Because the empirical strategy assumes that the questions used are a good proxy, the results will inevitably be affected if the variables for the unfairness of income distribution cannot be used as proxies for the demand for redistribution itself.

\section{Preliminary results}

As a first step, it is useful to relate the variables of interest. Figure 3 relates the demand for redistribution with the average expectation of future mobility in the countries of Latin America. The mobility variable works as a measure of optimism: the greater people's 


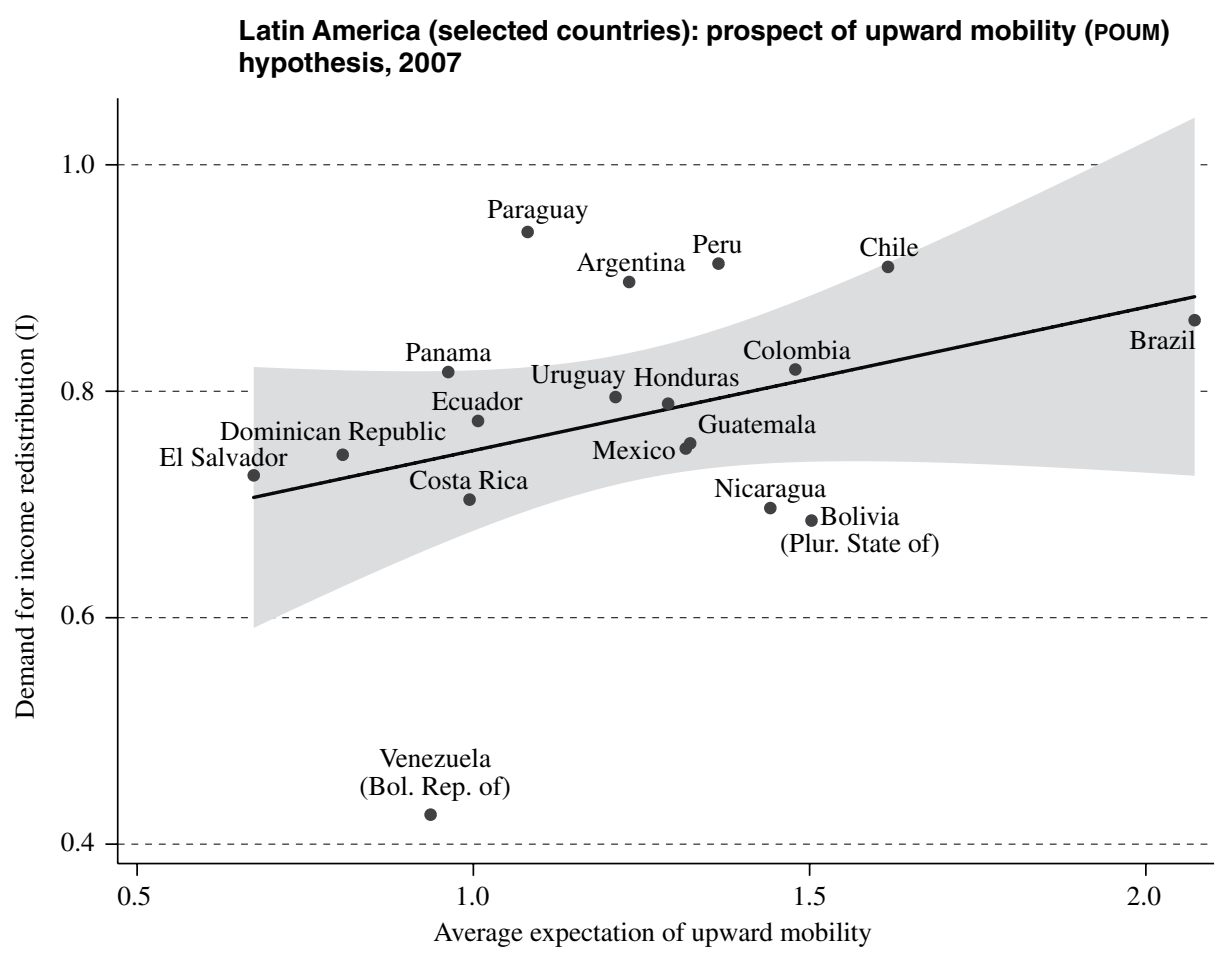

Source: prepared by the authors on the basis of Latinobarómetro data.

belief that their children will attain a better position, the higher it is. Consequently, POum predicates an inverse movement between these variables. The relationship actually proves to be direct, however, since the greatest demand for redistribution is found precisely in countries where, on average, people expect their children to be better placed than them. The case of Brazil sums up this interpretation well.

To examine the relationship between the prospect of mobility and the demand for redistribution, table 1 presents the demand for redistribution relative to every combination between the income strata of the respondent and the respondent's parents and children. The purpose of this strategy is to determine how the demand for redistribution varies with the prospects perceived by individuals. In other words, does mobility actually matter?

According to the data, it does: respondents calling for the redistribution of income are considering the perceived position of their parents and the position they expect for their children. Of individuals stating that their incomes are below the average and that their parents are in the same position, $80.57 \%$ call for redistribution. The proportion is about $4 \%$ higher when agents infer that their parents were better off. In other words, even among those considering themselves poor today, the demand for redistribution differs systematically with the position they believe they are in relative to their parents. An intergenerational drop in income level increases the demand for redistribution, which indicates the importance of past mobility. The opposite also holds: even among agents with high incomes, views differ by the declared stratum of the parents, with respondents who consider their parents to have been at a lower level being more receptive to redistribution mechanisms.

\begin{tabular}{|c|c|c|c|}
\hline & \multicolumn{3}{|c|}{$\begin{array}{l}\text { Latin America (selected countries): demand } \\
\text { for redistribution by mobility prospects } \\
\text { (Percentages) }\end{array}$} \\
\hline & & Low incomes & High incomes \\
\hline \multirow[t]{2}{*}{ Parents } & Low incomes & 80.57 & 75.47 \\
\hline & High incomes & 84.06 & 70.21 \\
\hline \multirow[t]{2}{*}{ Children } & Low incomes & 82.69 & 70.58 \\
\hline & High incomes & 80.91 & 70.51 \\
\hline
\end{tabular}

Source: prepared by the authors on the basis of data from Latinobarómetro, 2007.

Note: low incomes $=1$ to 4 and high incomes $=7$ to 10 . 
Where respondents' children are concerned, the analysis produces identical results, except at the upper income level. Among agents who see themselves as poor, there is a differentiation, albeit a small one, by the level of income they expect for their children. When the children are expected to move up in society, the demand for redistribution is less. This finding tells in favour of POum in Latin America. However, there is no differentiation among respondents who consider themselves rich, since demand for redistribution is almost the same regardless of the position they expect for their children. This runs counter to the "tunnel effect" of Hirschman and Rothschild (1973).

In summary, these findings indicate that past mobility has a greater influence than expectations of future mobility, even when current income levels are controlled for. Of all the possible combinations, the greatest demand for redistribution is found in the group of those on low incomes who perceive themselves to be worse off than their parents. There is greater demand in this group even than in the group of respondents who consider themselves poor and expect this status to continue into the next generation. This is not exactly surprising. Piketty (1995) showed that the experience of past mobility could have persistent effects on attitudes to the redistribution of current income. ${ }^{4}$ Among other things, this explains why people with the same level of income display different redistribution preferences. Empirically, past mobility is thus an important control variable when the effect of current income on redistribution preferences is estimated.

Table 2 shows the percentages of respondents calling for redistribution in four categories: (a) the total; (b) those expecting their children to have higher incomes (future mobility $>0$ ); (c) those expecting their children to have lower incomes (future mobility $<0$ ); and (d) those who

\footnotetext{
4 Another explanation can be found in behavioural economics, where questions are used to capture perceptions based on respondents' prior experience. Following Kahneman, Wakker and Sarin (1997), it can be seen that the strategies adopted work with the utility experienced and not with the utility of the decision. Furthermore, according to the authors, losses have greater repercussions than equivalent gains. This helps to explain why an intergenerational reduction in income affects demand for redistribution. Lastly, it also helps to explain why POUM findings are rebutted and serves as a critique of the strategy adopted by Ravallion and Lokshin (2000) and in much of the literature.
}

TABLE 2

Latin America (selected countries): respondents calling for income redistribution (Percentages)

\begin{tabular}{lcccc}
\hline Region & Total (a) & Best stratum (b) & Worst stratum (c) & POUM ${ }^{\mathrm{a}}(\mathrm{d})$ \\
\hline Latin America & 78.05 & 77.82 & 82.22 & 80.91 \\
Argentina & 89.64 & 89.82 & 94.59 & 83.96 \\
Bolivia (Plurinational State of) & 68.59 & 66.46 & 77.33 & 60.46 \\
Brazil & 86.27 & 86.81 & 82.35 & 86.44 \\
Colombia & 81.91 & 81.48 & 92.15 & 80.31 \\
Costa Rica & 70.43 & 68.60 & 69.11 & 72.50 \\
Chile & 90.97 & 91.18 & 87.87 & 93.06 \\
Ecuador & 77.39 & 74.53 & 82.08 & 80.64 \\
El Salvador & 72.58 & 71.56 & 85.84 & 74.07 \\
Guatemala & 75.40 & 73.60 & 77.58 & 74.19 \\
Honduras & 78.89 & 78.93 & 76.25 & 80.80 \\
Mexico & 74.95 & 72.88 & 82.27 & 76.99 \\
Nicaragua & 69.68 & 68.92 & 71.42 & 77.55 \\
Panama & 81.71 & 84.53 & 87.77 & 86.95 \\
Paraguay & 94.08 & 94.76 & 92.47 & 96.09 \\
Peru & 91.26 & 90.45 & 98.75 & 93.69 \\
Uruguay & 79.50 & 78.46 & 84.37 & 86.92 \\
Venezuela (Bolivarian Republic of) & 42.59 & 37.53 & 63.97 & 54.23 \\
Dominican Republic & 74.40 & 72.85 & 83.49 & 74.35 \\
\hline
\end{tabular}

Source: prepared by the authors on the basis of data from Latinobarómetro, 2007.

a Prospect of upward mobility. 
are in a lower stratum and expect their children to move up to a higher one. ${ }^{5}$

At this point, a proviso should be mentioned. Alesina and Giuliano (2009) distinguish two interpretations of POUM. According to the first, which is the weaker, social mobility interacts with redistribution preferences. From this point of view, the earlier analysis confirms the hypothesis, at least where respondents with below-average incomes are concerned. In the context of table 2 , it is only required that (c) $>$ (a) $>$ (b). The second interpretation, which is more rigorous because based on a fuller context of rationality, is actually the one put forward by Benabou and Ok (2001). The idea is that agents base their thinking on the average income level and only cease to call for redistribution if they expect a move to the higher income level in future. Thus, agents who expect their children to be better off than them but not necessarily to move up to a higher level will still call for redistribution. Consequently, in the context of table 2 , (d) $<$ (b).

To sum up, the findings show that the demand for income redistribution is greatest among respondents who expect their children to be worse positioned than them in society. This holds true for Latin America generally and for most of the countries. Only Brazil, Chile, Costa Rica, Honduras, Panama and Paraguay are exceptions to this model. Although POUM is confirmed insofar as mobility influences redistribution preferences, strictly speaking the hypothesis is not supported by the results. Overall, the demand for redistribution in group (d) is greater than total undifferentiated demand (a).

Strictly speaking, the expected behaviour is found in Argentina, Colombia and the Plurinational State of Bolivia. The Plurinational State of Bolivia is an emblematic case, as $68.59 \%$ of respondents there call for income redistribution. However, the proportion is lower $(66.46 \%)$ among those expecting a higher level of income for their children (b) and lower still (60.46\%) under the conditions proposed by POUM (d). In other words, POUM does seem to operate in this specific case.

\section{Regressions for Latin America}

The regression results are detailed in table 3 . The estimates will make use of a logistic model with robust standard deviations for the two variables serving as proxies for the demand for redistribution. Since the questions are similar, a solid result should agree on both measures.

\footnotetext{
5 Once again, 1 to 4 were taken as the lower stratum and 7 to 10 as the upper stratum.
}

The individual characteristics used were not significant. It cannot be argued, for example, that demand for redistribution is higher among women and older adults than others, as Ravallion and Lokshin (2000) found on the basis of Russian data. The positive and significant income variable represents demand deriving from selfinterest. Those who consider their incomes inadequate call for redistribution. This result is not maintained for the second variable, however, which confirms the difficulty discussed earlier of capturing the effect of income level on the dependent variable.

Self-interested demand was confirmed from expectations of future income. Agents expecting their situation to worsen over the next 12 months are more likely to call for income redistribution. Other data can be captured by analysing the subjective mobility and inequality of opportunities variables. In the first place, there is greater demand from those who do not believe in the potential of effort: the subjective mobility variable is positive and quite significant. This finding for Latin America is close to that for the European countries analysed in Alesina and Angeletos (2005) and Alesina y Glaeser (2004). Consistently with this result, agents who perceive an inequality of opportunities are more sensitive to redistribution mechanisms, which bears out the finding of Gaviria (2007). ${ }^{6}$ Alesina and La Ferrara (2005) and Fong (2006) reached the same conclusion using United States data.

The significance and effect of education on the demand for income redistribution are striking. The preference for mechanisms of redistribution increases systematically with education, contrary to the model of Meltzer and Richard (1981) and most empirical studies. Although this result may be due to an education-correlated variable that was not included in the model, it does at all events indicate that the demand for redistribution increases with education. ${ }^{7}$

\footnotetext{
6 Initially, it can be argued that the inequality of opportunities variable becomes "confused" with the dependent variable, employed as a proxy for the demand for redistribution. However, the standard of fairness on which respondents form their preferences is unknown a priori. The findings presented indicate that the Latin American perception is similar to the view taken by modern egalitarians. It is possible to perceive inequality of opportunities yet not to call for redistribution of income because the standard taken for this is strict inequality, for instance. In any event, the perception of inequality of opportunities is widely used as a proxy in the literature.

7 Analysing the exact reasons for this is beyond the scope of this study. Nonetheless, if the theory of the omitted variable is accepted, and bearing in mind the relationship between political stances and the demand for redistribution, a positive correlation between education and "left-wing" political views could produce this result. That would imply a powerful system of ideological perpetuation.
} 
Latin America (selected countries): income redistribution preferences

\begin{tabular}{|c|c|c|}
\hline & Demand for redistribution (I) & Demand for redistribution (II) \\
\hline Constant & $\begin{array}{l}-0.3163^{*} \\
(0.1741) \\
\end{array}$ & $\begin{array}{l}-0.2955^{*} \\
(0.1780) \\
\end{array}$ \\
\hline \multicolumn{3}{|l|}{ Individual characteristics } \\
\hline Female & $\begin{array}{c}0.0834 \\
(0.0659)\end{array}$ & $\begin{array}{l}-0.0405 \\
(0.0653)\end{array}$ \\
\hline Age & $\begin{array}{l}-0.0005 \\
(0.0025)\end{array}$ & $\begin{array}{c}0.0022 \\
(0.0025)\end{array}$ \\
\hline Married & $\begin{array}{c}0.0188 \\
(0.0660) \\
\end{array}$ & $\begin{array}{c}0.0754 \\
(0.0655) \\
\end{array}$ \\
\hline \multicolumn{3}{|l|}{ Education } \\
\hline Basic & $\begin{array}{l}0.4414 * * * \\
(0.1199)\end{array}$ & $\begin{array}{c}0.1344 \\
(0.1230)\end{array}$ \\
\hline Secondary & $\begin{array}{l}0.6359 * * * \\
(0.1226)\end{array}$ & $\begin{array}{l}0.4368 * * * \\
(0.1264)\end{array}$ \\
\hline Higher & $\begin{array}{l}0.8220 * * * \\
(0.1340) \\
\end{array}$ & $\begin{array}{l}0.5309 * * * \\
(0.1369) \\
\end{array}$ \\
\hline \multicolumn{3}{|l|}{ Self-interest } \\
\hline Current income & $\begin{array}{l}0.2304 * * * \\
(0.0685)\end{array}$ & $\begin{array}{c}0.0230 \\
(0.0667)\end{array}$ \\
\hline Future income & $\begin{array}{l}0.8394 * * * \\
(0.1051)\end{array}$ & $\begin{array}{l}0.4578 * * * \\
(0.0939)\end{array}$ \\
\hline Risk aversion & $\begin{array}{l}-0.1596^{* *} \\
(0.0674) \\
\end{array}$ & $\begin{array}{l}-0.0733 \\
(0.0664) \\
\end{array}$ \\
\hline \multicolumn{3}{|l|}{ Perception of mobility } \\
\hline Subjective & $\begin{array}{l}0.4870 * * * \\
(0.0689)\end{array}$ & $\begin{array}{l}0.3063 * * * \\
(0.0677)\end{array}$ \\
\hline Past & $\begin{array}{l}-0.0422 * * \\
(0.0176)\end{array}$ & $\begin{array}{l}-0.0407 * * \\
(0.0178)\end{array}$ \\
\hline Future & $\begin{array}{c}0.0227 \\
(0.0172) \\
\end{array}$ & $\begin{array}{l}-0.0104 \\
(0.0170)\end{array}$ \\
\hline \multicolumn{3}{|l|}{ Fairness } \\
\hline Inequality of opportunities & $\begin{array}{l}0.9726 \text { *** } \\
(0.0627) \\
\end{array}$ & $\begin{array}{l}1.4823 * * * \\
(0.0638)\end{array}$ \\
\hline Number of observations & 5848 & 5911 \\
\hline Pseudo $R^{2}$ & 0.0771 & 0.1047 \\
\hline
\end{tabular}

Source: prepared by the authors on the basis of the estimation results.

Note: standard deviation in parentheses.

$* \mathrm{p}<0.10, * * \mathrm{p}<0.05$ and $* * * \mathrm{p}<0.01$.

The past mobility variable is negative and significant. Agents call for redistribution when they perceive their living standards to be lower than their parents'. Given the preliminary data, this is a predictable finding that demonstrates the importance of the yardsticks against which people measure their economic situation. Individuals may come out in favour of redistribution even when they are not at a low income level, as it is enough for them to feel that they are worse off than the previous generation.

This variable is an important control mechanism for the Poum test. When it is excluded from the model, the reason for agents not to be calling for redistribution may be that they perceive they have better incomes than their parents, and not that they expect their position to improve in future. In some studies, such as Corneo and Gruner (2002), past mobility is used in the POUM test in the absence of a measure of future expectations. The basic argument is that, in an information-poor context where individuals do not know exactly what their prospects of social advancement are, experience of past mobility might be extrapolated into the future. The results analysed, and especially those in table 1 , 
indicate that this is not a reasonable assumption. Because the experience of mobility is an important determinant of demand for redistribution, this strategy could result in unjustified acceptance of the hypothesis.

As expected, the data for the Latin American countries do not bear out the POUm hypothesis. As can be seen from figure 3 , the parameter associated with future mobility, while not significant, is positive with respect to the first variable. The bar is not set high: a negative and significant parameter would indicate a lesser demand for redistribution on the part of individuals optimistic about their children's position, irrespective of the income levels expected. POUM, it should be recalled, is linked to a very important premise: that redistribution policies persist for long periods. This premise can lose credibility in, essentially, two situations: (i) when agents do not believe that redistributive policies will be maintained, so that there would be no point in opposing redistribution, even if there were an expectation of future upward mobility; (ii) when agents think in terms of shorter periods than the one required by POUM. Point (i) is especially important in contexts of political instability. For expectations of future income, which proved significant, a period of 12 months was taken. Contradicting the underlying premise, this finding indicates that agents work to a shorter planning horizon than the one required by the POUm hypothesis.

It is interesting to observe the marginal effect of the variables on the likelihood of income redistribution being called for (see table 4). Other things being equal, those who believe that equality of opportunities is not guaranteed are $19.36 \%$ more likely to call for redistribution than those who believe that it is. This is the largest marginal effect in relation to the significant variables. The likelihood of redistribution being called for also tends to increase with education level.

TABLE 4

Latin America (selected countries): probability of respondents calling for income redistribution relative to the base group (Percentages)

\begin{tabular}{lc}
\hline Variable & Probability \\
\hline Basic education & 10.51 \\
Secondary education & 14.39 \\
Higher education & 17.43 \\
Current income & 5.68 \\
Future income & 17.68 \\
Subjective mobility & 11.48 \\
Inequality of opportunities & 19.36 \\
Past mobility & -1.05 \\
\hline
\end{tabular}

Source: prepared by the authors on the basis of the estimation results.
Respondents who expect their situation to worsen in the next 12 months are $17.68 \%$ more likely to call for income redistribution than those who expect their situation to improve. For each level of improvement perceived by respondents relative to their parents, they become about $1 \%$ less likely to call for redistribution. Applying the same reasoning, the marginal effects of the subjective mobility and income variables are $11.48 \%$ and $5.68 \%$, respectively. 8

This indicates that the sense of fairness may have a greater effect than self-interest variables such as current income and expectations of future income, and than belief in the role of effort in determining income (summarized in this case by subjective mobility). This being so, reducing inequality of opportunities would not only have a positive effect in itself but would help to reduce the demand for redistribution and break the vicious circle of high taxes, low investment and disincentives to effort.

The specific regression by countries yields further data on top of those of the aggregate analysis. The main results are detailed in annex B. The parameters relating to the perception of inequality of opportunities stand out, since that variable is significant in the great majority of countries. Thus, the demand for income redistribution in Latin America is definitely motivated in part by a sense of fairness. On the whole, these results do not have the same explanatory power as the aggregate results, as they are not a good match in respect of the two proxies used. Furthermore, the results of some variables that were significant for the region as a whole did not hold up in specific cases. In summary, income redistribution preferences vary from country to country. As Alesina and Giuliano (2009) emphasize, differences in religion, culture and macroeconomic variability may account for the variation in results.

According to the preliminary analysis, the POUM hypothesis is not rejected in the Plurinational State of Bolivia. By virtue of the results for both variables, it cannot be ruled out in the Bolivarian Republic of Venezuela, El Salvador, Nicaragua or Peru. Although they do not strictly meet the requirements (see table 2), these are countries where expectations of future mobility are incorporated into the demand for redistribution $(c>a>b)$.

\footnotetext{
8 To calculate the marginal effects, $k(1-k) \beta$ was taken, where $k=e^{\left(\beta^{\prime} x\right)} /\left(1+e^{\left(\beta^{\prime} x\right)}\right)$. In the case of the dichotomous variables, $x=1$ in this formula. The parameter estimated for the first redistribution demand variable was used in the calculation.
} 


\section{IV}

\section{Final considerations}

Data on the evolution of social spending and government size in Latin America have fed into the debate on the demand for income redistribution. This study has analysed the formation of redistribution preferences in the region. The results bear out some of the findings reported in the literature. The demand for redistribution in Latin America is not due to specific individual characteristics but is determined above all by education level, self-interest and a sense of fairness associated with belief in equality of opportunities.

A perceived reduction in inequality of opportunities can reduce the demand for redistribution and help to break the vicious circle of high taxes, low investment and disincentives to effort. Rewards for effort and recognition of their existence by agents set the Latin American situation apart from that of the European countries.

The hypothesis that there is less demand for redistribution among agents who expect to rise in the social scale was also tested. In contrast to what has been stated by Alesina and La Ferrara (2005), Ravallion and Lokshin (2000) and other authors in respect of various regions, Latin Americans do not present the behaviour expected by Benabou and Ok (2001). Agents do not think in terms of average income, and they call for income redistribution even when they expect their children to attain a higher level of income. 
ANNEX A

\section{Questionnaire}

\section{Demand for income redistribution (I)}

In your opinion, how fair is the distribution of income in the country?

(1) Unfair or very unfair; (0) Fair or very fair.

\section{Demand for income redistribution (II)}

How fairly is wealth distributed in the country?

(1) Not very or not at all; (0) Somewhat or completely.

\section{Female}

(1) Female; (0) Male

\section{Married}

(1) Married/Cohabiting; (0) Single/Separated/Divorced/ Widowed

\section{Education}

Seven groups are distinguished in the survey: illiterate, incomplete basic education, complete basic education, incomplete secondary (intermediate, technical) education, complete secondary (intermediate, technical) education, incomplete higher education and complete higher education. The level was taken irrespective of completion or non-completion. In other words, basic education = incomplete basic + complete basic. The same holds for secondary and higher education. The illiterate group was omitted from the regression and taken as the base group for comparing the results.

\section{Current income}

Are the pay you receive and your family's total income enough to meet your needs satisfactorily? Which of the following describes you? (1) They are not enough. You have difficulty or great difficulty; (0) They are enough for you to live on without great difficulty.

\section{Future income}

In the next 12 months, do you think your own and your family's situation will be:

(1) Somewhat or much worse? (0) Somewhat or much better?

\section{Risk aversion}

How concerned would you say you are about becoming jobless or unemployed in the next 12 months?

(1) Concerned or very concerned; (0) Not very or not at all concerned.

\section{Subjective mobility}

In (country of reference), do you think that someone who is born poor and works hard can become rich, or don't you think it is possible for someone born poor to become rich?

(1) It is not possible for someone born poor to become rich; (0) Someone who is born poor and works hard can become rich.

\section{Perceived inequality of opportunities}

How equal are the opportunities people have in the country, regardless of their origin?

(1) Not very or not at all equal; (0) Somewhat or completely equal.

\section{Past mobility and future mobility}

These variables were constructed following Gaviria (2007). Consider the following questions: "Imagine a 10 -point scale, with 1 being the poorest people and 10 the richest. Where are you on the scale? Where would your parents be? Where do you think your children will be?" From the respondent's point of view:

$$
\begin{gathered}
\text { Past mobility = } \\
\text { where I am - where my parents were }
\end{gathered}
$$

Future mobility $=$

expectation of where my children will be - where I am

Note that these variables lie along the range of $-9(1-10)$ to $9(10-1)$. The higher the value assigned to past mobility, the better the current situation will be compared to that of the past. The higher the value assigned to future mobility, the better off the respondents' children will be relative to themselves. 
ANNEX B

TABLE B. 1

Latin America (selected countries): income redistribution preferences (I)

(Dependent variable: demand for income redistribution)

\begin{tabular}{|c|c|c|c|c|c|c|c|c|}
\hline & Argentina & $\begin{array}{c}\text { Bolivia } \\
\text { (Plurinational } \\
\text { State of) }\end{array}$ & Brazil & El Salvador & Mexico & Nicaragua & Peru & $\begin{array}{l}\text { Venezuela } \\
\text { (Bolivarian } \\
\text { Republic of) }\end{array}$ \\
\hline Constant & $1.9098 *$ & -0.5375 & -0.6246 & $-2.9916 * * *$ & -0.6641 & 0.2693 & $17.0669 * * *$ & 0.5058 \\
\hline \multicolumn{9}{|c|}{ Individual characteristics } \\
\hline Female & 0.3705 & -0.1428 & 0.1635 & $0.9243 * *$ & -0.0815 & $0.5797 *$ & -0.1396 & 0.3669 \\
\hline Age & -0.0093 & 0.0077 & $0.0240 *$ & 0.0161 & 0.0228 & $-0.0188 * *$ & $-0.0292 *$ & $-0.0231 *$ \\
\hline Married & -0.5511 & 0.0356 & 0.1704 & 0.4216 & -0.4888 & $0.6566 * *$ & 0.1783 & -0.0566 \\
\hline \multicolumn{9}{|l|}{ Education } \\
\hline Basic & $-1.0921 * * *$ & $0.8040 *$ & 0.9232 & 0.4730 & 0.7507 & 0.3520 & $-13.6711 * * *$ & $-1.7593^{* *}$ \\
\hline Secondary & $-1.2616^{* *}$ & 0.6135 & $1.9284 * * *$ & $1.0199 *$ & 0.8463 & 0.0802 & $-15.1011 * * *$ & $-2.0923 * * *$ \\
\hline Higher & $\mathrm{n} / \mathrm{a}$ & $1.4800 * * *$ & $1.6537 * *$ & $3.6116^{* *}$ & 0.9893 & 0.9741 & $-14.4336^{* * * *}$ & $-1.5446^{*}$ \\
\hline \multicolumn{9}{|l|}{ Self-interest } \\
\hline Current income & 1.0710 & 0.1657 & -0.2198 & 0.1423 & 0.2397 & 0.1941 & $0.8083^{*}$ & 0.0598 \\
\hline Future income & $1.8864 * *$ & 0.5052 & $\mathrm{n} / \mathrm{a}$ & $1.6224 * * *$ & $0.7986^{* *}$ & 0.3260 & -0.5797 & $1.6862 * * *$ \\
\hline Risk aversion & 0.4009 & -0.2813 & 0.0525 & 0.3958 & -0.0307 & $-0.6367 * *$ & 0.2328 & 0.2246 \\
\hline \multicolumn{9}{|c|}{ Perception of mobility } \\
\hline Subjective & 0.4711 & -0.0549 & 0.3482 & 0.5438 & 0.4479 & 0.0740 & 0.3020 & $0.6266^{* *}$ \\
\hline Past & $0.2542 *$ & -0.0942 & $-0.1830 * *$ & -0.0579 & -0.0097 & -0.0976 & -0.0512 & -0.0684 \\
\hline Future & 0.1150 & $-0.1221^{*}$ & -0.0369 & $-0.2985 * *$ & -0.0130 & -0.0905 & -0.0781 & 0.0046 \\
\hline \multicolumn{9}{|l|}{ Fairness } \\
\hline $\begin{array}{l}\text { Inequality of } \\
\text { opportunities }\end{array}$ & $1.4587 * * *$ & $1.0529 * * *$ & $0.5352 *$ & $1.9534 * * *$ & 0.2794 & $0.7562 * * *$ & $1.0600 * * *$ & $1.9807 * * *$ \\
\hline $\begin{array}{l}\text { Number of } \\
\text { observations }\end{array}$ & 243 & 367 & 433 & 228 & 384 & 288 & 345 & 501 \\
\hline Pseudo $R^{2}$ & 0.1838 & 0.0893 & 0.0722 & 0.3246 & 0.0474 & 0.0842 & 0.1028 & 0.2914 \\
\hline
\end{tabular}

Source: prepared by the authors on the basis of the estimation results.

Note: $* \mathrm{p}<0.10, * * \mathrm{p}<0.05$ and $* * * \mathrm{p}<0.01$ 
TABLE B. 2

Latin America (selected countries): income redistribution preferences (II)

(Dependent variable: demand for income redistribution)

\begin{tabular}{|c|c|c|c|c|c|c|c|c|}
\hline & Argentina & $\begin{array}{c}\text { Bolivia } \\
\text { (Plurinational } \\
\text { State of) }\end{array}$ & Brazil & El Salvador & Mexico & Nicaragua & Peru & $\begin{array}{l}\text { Venezuela } \\
\text { (Bolivarian } \\
\text { Republic of) }\end{array}$ \\
\hline Constant & $1.7739 * *$ & -0.7246 & 0.3928 & -0.3062 & -1.1874 & 0.3308 & $1.8490 * *$ & -0.9072 \\
\hline \multicolumn{9}{|c|}{ Individual characteristics } \\
\hline Female & -0.3626 & 0.2282 & 0.3352 & $-0.9797 * * *$ & -0.1485 & -0.1415 & 0.1627 & 0.1948 \\
\hline Age & -0.0105 & 0.0105 & 0.0047 & 0.0000 & 0.0097 & 0.0028 & -0.0179 & $-0.0286 * *$ \\
\hline Married & 0.0586 & -0.4030 & 0.0136 & -0.2760 & 0.1774 & -0.1804 & -0.0127 & $0.6790 * * *$ \\
\hline \multicolumn{9}{|l|}{ Education } \\
\hline Basic & -1.0169 & 0.5487 & 0.2874 & 0.3668 & 1.0259 & -0.0912 & -0.2370 & 0.2185 \\
\hline Secondary & $-1.6857 * * *$ & 0.6367 & $1.2301 *$ & 0.5728 & $1.1935^{*}$ & $0.8314 * *$ & -0.5039 & -0.4329 \\
\hline Higher & $\mathrm{n} / \mathrm{a}$ & 0.2771 & 1.2670 & $1.4211 * *$ & $1.7112^{* *}$ & $2.2843 * * *$ & -0.6491 & -0.2078 \\
\hline \multicolumn{9}{|l|}{ Self-interest } \\
\hline Current income & 0.3773 & -0.0507 & $0.6375^{* *}$ & 0.2567 & 0.1500 & 0.4917 & $-0.5672 *$ & 0.1747 \\
\hline Future income & $1.7895 *$ & 0.2029 & 1.1799 & $0.8611 * *$ & 0.5174 & 0.4204 & 0.1252 & 0.1984 \\
\hline Risk aversion & 0.5985 & 0.1729 & -0.5217 & -0.2204 & -0.4296 & $-1.0442 * * *$ & 0.1552 & 0.1988 \\
\hline \multicolumn{9}{|c|}{ Perception of mobility } \\
\hline Subjective & $1.0410 * *$ & -0.3939 & -0.1159 & 0.1345 & 0.5185 & -0.1667 & $0.7776^{* *}$ & $0.6572 * *$ \\
\hline Past & 0.1294 & -0.0646 & 0.0349 & -0.0770 & $-0.2192 * * *$ & -0.0943 & 0.0301 & 0.0007 \\
\hline Future & -0.0454 & 0.0170 & 0.0230 & 0.0209 & -0.0690 & $-0.1314 * *$ & $-0.1531 * *$ & $-0.1609 * *$ \\
\hline \multicolumn{9}{|l|}{ Fairness } \\
\hline $\begin{array}{l}\text { Inequality of } \\
\text { opportunities }\end{array}$ & $1.8584 * * *$ & $1.1458 * * *$ & $0.9705 * * *$ & $1.6448 * * *$ & $1.3800 * * *$ & $1.1167 * * *$ & $1.3669 * * *$ & $2.4973 * * *$ \\
\hline $\begin{array}{l}\text { Number of } \\
\text { observations }\end{array}$ & 248 & 373 & 455 & 232 & 383 & 296 & 350 & 512 \\
\hline Pseudo $R^{2}$ & 0.2143 & 0.0697 & 0.0937 & 0.1854 & 0.1350 & 0.1365 & 0.1160 & 0.2703 \\
\hline
\end{tabular}

Source: prepared by the authors on the basis of the estimation results.

Note: $* \mathrm{p}<0.10, * * \mathrm{p}<0.05$ and $* * *<0.01$. 
Alesina, A. and G. Angeletos (2005), "Fairness and redistribution", American Economic Review, vol. 95, No. 4, Nashville, Tennessee, American Economic Association.

Alesina, A. and N. Fuchs (2007), "Goodbye Lenin (or not?): the effect of communism on peoples", American Economic Review, vol. 97, No. 4, Nashville, Tennessee, American Economic Association.

Alesina, A. and E. Glaeser (2004), Fighting Poverty in the U.S. and Europe: A World of Difference, New York, Oxford University Press.

Alesina, A. and P. Giuliano (2009), "Preferences for redistribution", NBER Working Paper, No. 14825, Cambridge, Massachusetts, National Bureau of Economic Research.

Alesina, A. and G. La Ferrara (2005), "Preferences for redistribution in the land of opportunities", Journal of Public Economics, vol. 89, No. 5-6, Amsterdam, Elsevier.

Ames, B. and A.E. Smith (2010), "Knowing left from right: ideological identification in Brazil, 2002-2006", Journal of Politics in Latin America, vol. 2, No. 3, Hamburg, Hamburg University Press.

Benabou, R. and E.A. Ok (2001), "Social mobility and the demand for redistribution: the Poum hypothesis", Quarterly Journal of Economics, vol. 116, No. 2, Oxford, Oxford University Press.

Corneo, G. (2001), "Inequality and the State: comparing U.S. and German preferences", Annales d'économie et de statistique, No. 63-64, Association pour le développement de la recherche en économie et en statistique.

Corneo, G. and H. Gruner (2002), "Individual preferences for political redistribution”, Journal of Public Economics, vol. 83, No. 1, Amsterdam, Elsevier.

Fong, C. (2006), Prospective Mobility, Fairness and Demand for Redistribution, Pittsburgh, Department of Social and Decision Sciences, Carnegie Mellon University.
(2001), "Social preferences, self-interest, and the demand for redistribution", Journal of Public Economics, vol. 82, No. 2, Amsterdam, Elsevier.

Gaviria, A. (2007), "Social mobility and preferences for redistribution in Latin America", Economía, vol. 8, No. 1, Bogota, Latin America and Caribbean Economic Association.

Hirschman, A. and M. Rothschild (1973), "The changing tolerance for income inequality in the course of economic growth", Quarterly Journal of Economics, vol. 87, No. 4, Oxford, Oxford University Press.

Kahneman, D., P. Wakker and R. Sarin (1997), "Back to Bentham? Explorations of experienced utility", The Quarterly Journal of Economics, vol. 122, No. 2, Oxford, Oxford University Press.

Meltzer, A. and S. Richard (1981), "A rational theory of the size of government", Journal of Political Economy, vol. 89, No. 5, Chicago, The University of Chicago Press.

Neustadt, I. and P. Zweifel (2009), "Economic well-being, social mobility, and preferences for income redistribution: evidence from a discrete choice experiment", Socioeconomic Institute Working Paper, No. 0909, Zurich, University of Zurich.

Piketty, T. (1995), "Social mobility and redistributive politics", Quarterly Journal of Economics, vol. 110, No. 3, Cambridge, Massachusetts, MIT Press.

Ravallion, M. and M. Lokshin (2000), "Who wants to redistribute? The tunnel effect in 1990s Russia", Journal of Public Economics, vol. 76, No. 1, Amsterdam, Elsevier.

Tocqueville, A. (2003), Democracy in America, New York, Penguin Classics. Originally published in 1835 . 